\title{
Systematic design of separation process for bioethanol production from corn stover
}

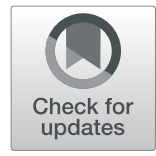

\author{
Suksun Amornraksa ${ }^{1 *}$, Ittipat Subsaipin ${ }^{1}$, Lida Simasatitkul ${ }^{2}$ and Suttichai Assabumrungrat ${ }^{3}$
}

\begin{abstract}
Separation process is very crucial in bioethanol production as it consumes the highest energy in the process. Unlike other works, this research systematically designed a suitable separation process for bioethanol production from corn stover by using thermodynamic insight. Two separation processes, i.e., extractive distillation (case 2) and pervaporation (case 3), were developed and compared with conventional molecular sieve (case 1). Process design and simulation were done by using Aspen Plus program. The process evaluation was done not only in terms of energy consumption and process economics but also in terms of environmental impacts. It was revealed that pervaporation is the best process in all aspects. Its energy consumption and carbon footprint are 60.8 and $68.34 \%$ lower than case 1, respectively. Its capital and production costs are also the lowest, 37.0 and $9.88 \%$ lower than case 1.
\end{abstract}

Keywords: Bioethanol, Corn stover, Process design, Economic analysis, Life cycle analysis

\section{Introduction}

Bioethanol $\left(\mathrm{C}_{2} \mathrm{H}_{5} \mathrm{OH}\right)$ has been well-accepted and used in the transportation sector worldwide. The firstgeneration bioethanol produced from food crops was found to be a suitable replacement for gasoline. It can be fully or partially blended with gasoline effectively. However, due to some considerable concern about competition with food crops [1], the second-generation bioethanol produced from biomass such as agricultural wastes has gained much more attention in recent years. Lignocellulosic biomass has a great potential to be used as feedstock for bioethanol production as it is cheap, abundant, sustainable, and does not compete with food [2]. There are enormous lignocellulosic biomass available around the world, especially corn stover. Each year corn stover is produced in vast quantities in many countries. The management of this agricultural waste is essential. Corn stover could be an excellent candidate for

\footnotetext{
* Correspondence: suksun.a@tggs.kmutnb.ac.th

${ }^{1}$ Chemical and Process Engineering Program, The Sirindhorn International

Thai-German Graduate School of Engineering (TGGS), King Mongkut's University of Technology North Bangkok, Bangkok 10800, Thailand Full list of author information is available at the end of the article
}

lignocellulosic resources for large scale ethanol production [3].

Generally, the bioethanol production process from lignocellulosic biomass consists of four main steps, which are pretreatment, hydrolysis, fermentation, and separation [4]. The pretreatment step is used to remove lignin and alter cellulose structures by increasing cellulose accessibility for a further hydrolysis process. During this step, hemicellulose inside the biomass is completely hydrolyzed into sugars, which can be directly converted to ethanol in a later fermentation process $[5,6]$. Furfural and 5-hydroxymethyl furfural (HMF) that act as fermentation inhibitors are also formed in this step.

The separation step is considered very important in the design of the bioethanol production process as it consumes the highest energy in the process. Several novel separation techniques have been developed to separate and purify ethanol more efficiently. In most cases, the distillation column is used as the critical method for separation due to its performance and reliability. However, the purification method used for ethanol dehydration may be various. The conventional method being

(C) The Author(s). 2020 Open Access This article is licensed under a Creative Commons Attribution 4.0 International License, which permits use, sharing, adaptation, distribution and reproduction in any medium or format, as long as you give appropriate credit to the original author(s) and the source, provide a link to the Creative Commons licence, and indicate if changes were made. The images or other third party material in this article are included in the article's Creative Commons licence, unless indicated otherwise in a credit line to the material. If material is not included in the article's Creative Commons licence and your intended use is not permitted by statutory regulation or exceeds the permitted use, you will need to obtain permission directly from the copyright holder. To view a copy of this licence, visit http://creativecommons.org/licenses/by/4.0/ The Creative Commons Public Domain Dedication waiver (http://creativecommons.org/publicdomain/zero/1.0/) applies to the data made available in this article, unless otherwise stated in a credit line to the data. 
used commercially is a molecular sieve by the adsorption process $[7,8]$. The principle of molecular sieve is based on the difference in molecular size between water and ethanol. Small molecules that can pass through the pores are adsorbed, while the larger molecules are not. Typically, the molecular sieve for ethanol dehydration has a pore diameter of $3 \mathrm{~A}^{\circ}$, capable of adsorbing water that has a diameter of $2.5-2.8 \mathrm{~A}^{\circ}$ but not ethanol that has a diameter of 4-4.4 $\mathrm{A}^{\circ}[9]$.

Besides the conventional molecular sieve, extractive distillation is another method that can be used to produce anhydrous ethanol. The extractive distillation involves two columns, which are extractive distillation column and recovery column [10]. A relatively nonvolatile liquid solvent such as ethylene glycol is used to change the relative volatilities of the components. In Meirelles et al. work [11], extractive distillation using ethylene glycol as a solvent was used for ethanol dehydration. The experimental and simulation results showed that extractive distillation could be used to achieve high purity of ethanol with low energy consumption. A comparison of three ethanol dehydration techniques, including azeotropic distillation, extraction, and adsorption was studied by Paola et al. [10]. It was revealed that extractive distillation with ethylene glycol as a solvent is the best choice in terms of operation and economics. The successful use of extractive distillation for bioethanol production has also been demonstrated by $D$. Chuenbubpar et al. [12].

Pervaporation is another promising separation technique that can be used to produce anhydrous ethanol $[13,14]$. Pervaporation is a kind of membrane separation processes [15]. Principally, a liquid feed is separated into two streams, which are permeate and retentate. The water passes through the membrane as vapor permeate, while the ethanol remains in the liquid phase as retentate. The driving force of pervaporation is a pressure difference created over the membrane. The vacuum is located on the permeate side while atmospheric pressure is operated on the feed side, causing the pressure difference.

Hafrat et al. [16] developed a modeling equation of pervaporation for dehydration of bioethanol by using Scilab software. The result showed that the pervaporation was able to break down the azeotrope of ethanolwater pointed out by Khan et al. [17]. Furthermore, Kunakorn et al. [18] compared azeotropic distillation using entrainer (i.e., benzene, cyclohexane) with distillation followed by pervaporation by using Pro II. They found that the azeotropic distillation provided $99 \mathrm{wt} . \%$ purity of ethanol, but its total cost was high due to high energy consumption. Thus, the hybrid system of distillation followed by pervaporation is the best in terms of techno-economic point of view. Another work on bioethanol production from corn stover was also done by Kazi et al. [19]. They designed and evaluated the economics of different process technologies for biochemical ethanol production from corn stover. Four pretreatment technologies and three downstream process variations, including Beer column, and pervaporation were investigated by using available data from previous works. However, they did not concern about the environmental impact of the process. The use of pervaporation for bioethanol production is still relatively new. Many works still need to be done to develop and prove its merit.

Thermodynamic insight is a methodology which employs physicochemical properties of the substances to be separated and their relationships to determine appropriate separation scheme. This methodology can be effectively used to design and synthesize the appropriate separation method [20]. Many research works have used thermodynamic insight into the design process. For example, Holtbruegge [21] used the thermodynamic insight for the conceptual design of flowsheet options that focus on process intensification. It was also used in conjunction with the Analytical Hierarchy Process (AHP), heuristic synthesis approaches, and new hybrid methodology to design and select suitable separation techniques by Li [22].

In this work, the thermodynamic insight was used as a tool to determine and select an appropriate separation process for bioethanol production from corn stover. Unlike other works, our designed processes are investigated and evaluated in terms of both economics and environmental impacts. The design and simulation of the process were performed by using the Aspen Plus simulation program. Two separation options, i.e., pervaporation and extractive distillation, were obtained from using the thermodynamic insight. They were evaluated together with the conventional molecular sieve process used in commercials to make a fair comparison (https://www. vogelbusch-biocommodities.com/process-units/dehydration/molecular-sieve-process/). The evaluation was done in terms of energy consumption, process economics, and environmental impacts. The results of this study are significant as they can be used as supporting data for future design and development of optimal and more efficient separation/purification schemes for bioethanol production.

\section{Methods}

The production process in this work consists of two sections: reaction and separation. The reaction occurred in the pretreatment step can be expressed by the following equations: The information of conversion of the reactions is provided in Additional file 1.

$$
\text { Glucan }+\mathrm{H}_{2} \mathrm{O} \rightarrow \text { Glucose }
$$




$$
\begin{aligned}
& \text { Glucan }+\mathrm{H}_{2} \mathrm{O} \rightarrow \text { Glucose Oligomer } \\
& \text { Glucan } \rightarrow \mathrm{HMF}+\mathrm{H}_{2} \mathrm{O} \\
& \text { Sucrose } \rightarrow \text { Xylan }+\mathrm{H}_{2} \mathrm{O} \rightarrow \text { Xylose } \\
& \text { Xylan }+\mathrm{H}_{2} \mathrm{O} \rightarrow \text { Xylose } \\
& \text { Xylan }+\mathrm{H}_{2} \mathrm{O} \rightarrow \text { Xylose Oligomer } \\
& \text { Xylan } \rightarrow \text { Furfural }+2 \mathrm{H}_{2} \mathrm{O} \\
& \text { Acetate } \rightarrow \text { Acetic Acid } \\
& \text { Lignin } \rightarrow \text { Soluble lignin }
\end{aligned}
$$

In the hydrolysis step, most celluloses are converted into fermentable sugars by some suitable enzymes such as Cellulase. This step is also known as enzymatic hydrolysis process and has the reactions as follows:

$$
\begin{aligned}
& \text { Glucan }+\mathrm{H}_{2} \mathrm{O} \rightarrow \text { Glucose Oligomer } \\
& \text { Glucan }+0.5 \mathrm{H}_{2} \mathrm{O} \rightarrow 0.5 \text { Cellobiose } \\
& \text { Glucan }+\mathrm{H}_{2} \mathrm{O} \rightarrow \text { Glucose } \\
& \text { Cellobiose }+\mathrm{H}_{2} \mathrm{O} \rightarrow 2 \text { Glucose }
\end{aligned}
$$

The fermentable sugars obtained from the pretreatment and hydrolysis steps are sent to a fermenter where they are fermented in the presence of specific microorganisms to produce ethanol. Then, the ethanol is separated from other impurities and purified by appropriate separation process $[7,23]$. The reactions that take place during the fermentation can be shown as below.

$$
\begin{aligned}
& \text { Glucose } \rightarrow 2 \mathrm{Ethanol}+2 \mathrm{CO}_{2} \\
& \text { Glucose }+2 \mathrm{H}_{2} \mathrm{O} \rightarrow 2 \text { Glycerol }+\mathrm{O}_{2} \\
& \text { Glucose }+2 \mathrm{CO}_{2} \rightarrow 2 \text { Succinic Acid }+\mathrm{O}_{2} \\
& 3 \text { Xylose } \rightarrow 5 \text { Ethanol }+5 \mathrm{CO}_{2} \\
& 3 \text { Xylose }+5 \mathrm{H}_{2} \mathrm{O} \rightarrow 5 \text { Glycerol }+2.5 \mathrm{O}_{2} \\
& \text { Xylose }+\mathrm{H}_{2} \mathrm{O} \rightarrow \text { Xylitol }+0.5 \mathrm{O}_{2} \\
& 3 \text { Xylose }+5 \mathrm{O}_{2} \rightarrow 5 \text { Succinic Acid }+2.5 \mathrm{O}_{2}
\end{aligned}
$$

Since this work focuses on the design of a suitable separation process, the reaction section is not of the primary concern. Therefore, we designed the reaction section of the bioethanol production from corn stover based on process data from work by Humbird et al. [7].

For the separation section, there are three different separation processes investigated in this work, namely, conventional molecular sieve (case 1), extractive distillation (case 2), pervaporation (case 3 ). The separation process of case 2 and case 3 are obtained from using the thermodynamic insight method, while case 1 is based on the industrial separation process used in large-scale production. The simulation of all processes is performed by using the Aspen Plus simulation software. Non-random two-liquid (NRTL) model was employed to the activity coefficients [10, 24]. The design basis is the plant capacity of approximately 24.5 tons/h, with the purity of product ethanol of $99 \%$ by weight. So raw material in case 1 , case 2 , and case 3 are required approximately $127 \mathrm{~T} / \mathrm{h}, 104 \mathrm{~T} / \mathrm{h}$, and 104 $\mathrm{T} / \mathrm{h}$, respectively. The results of the simulation are evaluated and compared in terms of energy consumptions, economics, and environmental impacts. The economic analysis is done based on a method of Guthrie [25], while environmental impacts assessment is done by using LCSoft program [26].

\section{Process design}

In our design, we applied the thermodynamic insight method to identify appropriate separation techniques to be used in the separation section of the process. The method employs physicochemical properties and their relationships to separation techniques. Therefore, properties of components are required, such as boiling point, vapor pressure, molecular diameter, molecular weight, kinetic diameter.

Different separations have different relationships between separation techniques and pure component properties, as shown in Table 1. For example, distillation needs properties of boiling point and vapor pressure, while molecular diameter (size) and molecular weight are required for microfiltration. The computation of the binary ratio of properties of binary pairs is shown in Eq. 21.

$$
r_{i j}=\frac{p_{A, j}}{p_{B, j}}
$$

Where subscripts $\mathrm{A}$ and $\mathrm{B}$ represent the two components for the binary pair $i . r_{i j}$ is the binary ratio showing the feasible use of separation techniques. Note that $P_{\mathrm{A}, j}$ is component properties of component $\mathrm{A}$ which should have a higher value than the component properties of component B. Information of the binary ratio of properties and a list of important pure component properties and their classification are provided in Additional file 1. All of those properties are considered thoroughly and compared with the recommended values for separation feasibility indices (see Additional file 1). If the value of a property for a particular separation technique is less than its recommended value, it is not appropriate or not feasible to use that technique for separation. 
Table 1 The methodology for dehydration process

\begin{tabular}{lll}
\hline Method for producing anhydrous ethanol & Recommended values for separation feasibility indices & Ratio of properties for Ethanol/Water \\
\hline Molecular sieve & Kinetic diameter $=1.05$ & - \\
& Van der Waals volume $=1.07$ & 1.71 \\
& Polarizability $=1.08$ & - \\
& Dipole moment $=1.05$ & 1.09 \\
Extractive distillation & Vapor pressure $=0.00$ & 2.49 \\
& Boiling point $=0.00$ & 1.28 \\
Pervaporation & Molar volume $=3.20$ & 3.23 \\
& Solubility parameter $=1.90$ & - \\
\hline
\end{tabular}

After the fermentation is complete, the presence of a fraction of suspended solids and other residues in the fermenter's effluent cause low fluidity, subsequently decreasing the efficiency of ethanol separation. Therefore, it is necessary to remove the suspended solids before the ethanol separation. Filtration was found to be an effective method to remove solids and other residues in the effluent stream (https://www.vogelbusch-biocommodities.com/processunits/dehydration/molecular-sieve-process/). After the solids are removed by filtration, a flash operation is employed to separate gas phase components from the liquid phase product. The flash operation can be used because the adjacent binary ratio of properties of components of ethanol/ $/ \mathrm{CO}_{2}$ is very high in terms of the boiling point and vapor pressure. Then, the liquid product from the flash operation is fed to a distillation column to concentrate the ethanol to a near azeotrope. Finally, the azeotropic mixture is sent to dehydration to produce high purity ethanol of $99 \%$ by weight. The feasible separation method for the dehydration in this research are identified from the molar volume, dipole moment, vapor pressure, and boiling point. Three feasible methods are chosen and investigated in this work, which are pervaporation, extractive distillation, and molecular sieve. These three methods were selected because the value of the ratio of properties for ethanol/water is higher than the recommended values for separation feasibility indices, as shown in Table 1. From the binary ratio of molar ratio between adjacent components, the ratio of water and ethanol is more dominant than vapor pressure. Thus, extractive distillation is preferable to simple distillation. From the binary ratio, ethanol and water

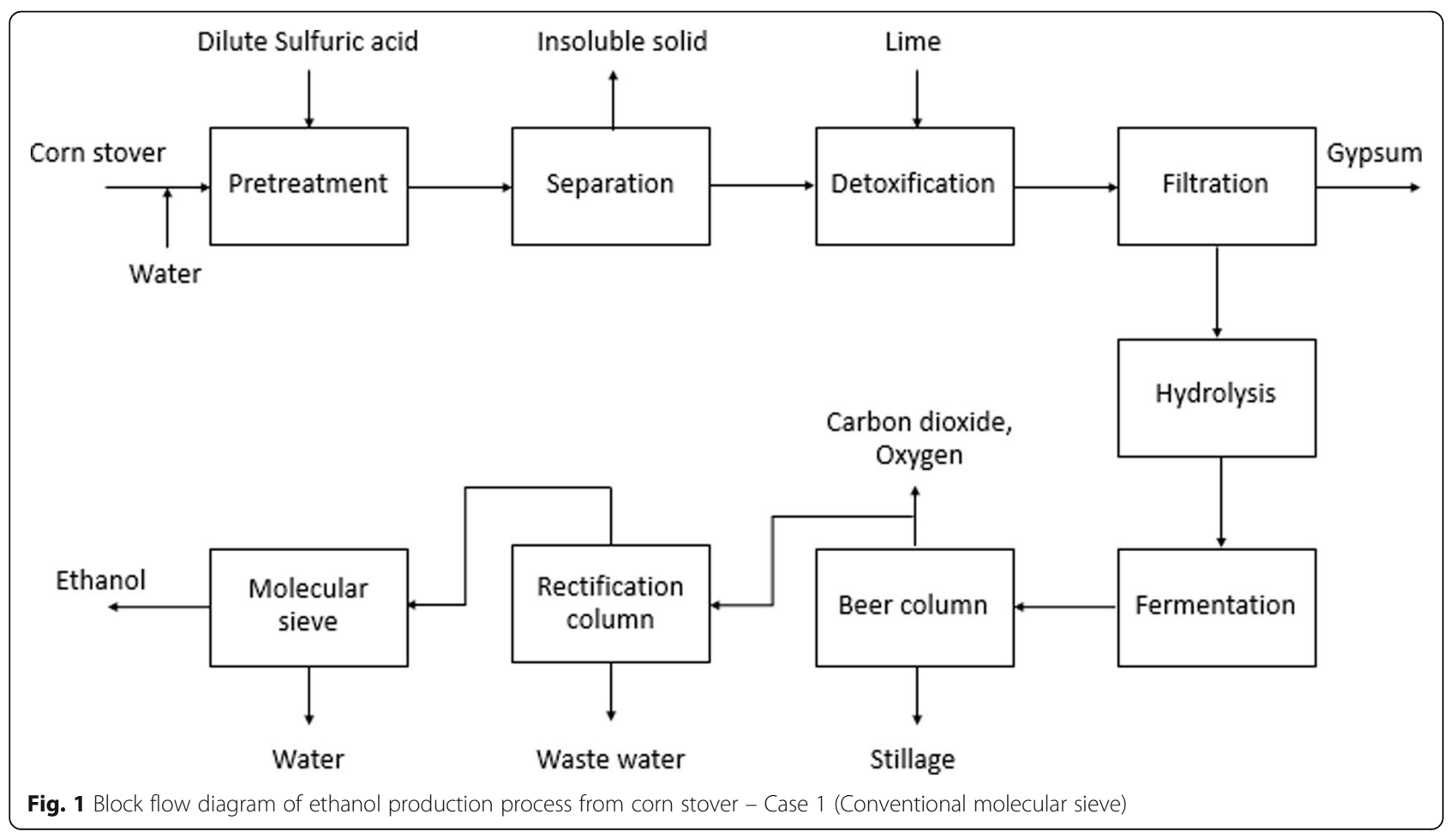


are key components. So light components are obtained at the top of the column, and heavy components leave at the bottom stream. It should be noted that the following assumptions were made for our designs: steady-state operation, counting the number of stages from top to bottom, including condenser and reboiler. Also, the heat integration of distillation was not considered.

\section{Process description \\ Conventional process}

As depicted in Fig. 1, corn stover feed is mixed with water. Then the mixed feed is sent to pretreatment where it is exposed to dilute sulfuric acid at a temperature of $158^{\circ} \mathrm{C}$. The hemicellulose inside the feed is converted to soluble sugars such as xylose, mannose, arabinose, and glucose via hydrolysis reaction. Fermentation inhibitors, such as furfural and 5-hydroxymethyl furfural (HMF), are also formed in this step [13]. The feed is then sent to a solid/liquid separator to remove insoluble solids. These two steps are the same as those in cases 1 and 2. After that, the feed is sent to detoxification to eliminate the fermentation inhibitors. Overliming is employed as a means to remove the inhibitors. Gypsum is produced as a by-product in this step [2729]. However, it is essential to note that using the overliming method has some drawbacks, as it can cause a sugar loss of about $10 \%$ through adsorption to lime [30]. Filtration is used to remove the produced gypsum in the feed before sending it to hydrolysis. In the hydrolysis, the cellulose inside the feed is converted into fermentable sugars by using cellulose enzymes. So, this step is also known as enzymatic hydrolysis [7, 31]. The hydrolysis is carried out at a temperature of $48^{\circ} \mathrm{C}$ [7]. The main components in the feed now are glucose and other sugars that are previously produced from the pretreatment step. The feed is then sent to fermenter operating at $32{ }^{\circ} \mathrm{C}$ to convert into ethanol by using suitable microorganisms [32]. The liquid product containing ethanol that is obtained from the fermentation is called beer or broth. In addition to a small portion of ethanol, the fermentation broth contains many impurities, and therefore it is necessary to separate them by proper separation methods. The state-of-the-art method is a series of distillation columns followed by a molecular sieve. First of all, the fermentation broth is sent to a Beer column. There, solid components are removed at the bottom as stillage while gaseous components such as dissolved $\mathrm{CO}_{2}$ are removed at the top. In the second distillation, called rectification column, water is separated and ethanol is concentrated to near azeotrope [7,33]. The product that is obtained by this series of distillation processes is called hydrous ethanol, which has a purity of ethanol about 95\%. However, this purity is still below the minimum purity requirement which is typically $99 \%$. Therefore, it is necessary to pass the hydrous ethanol to dehydration to purify it to anhydrous ethanol. This is conventionally done by molecular sieve [7, 34, 35].

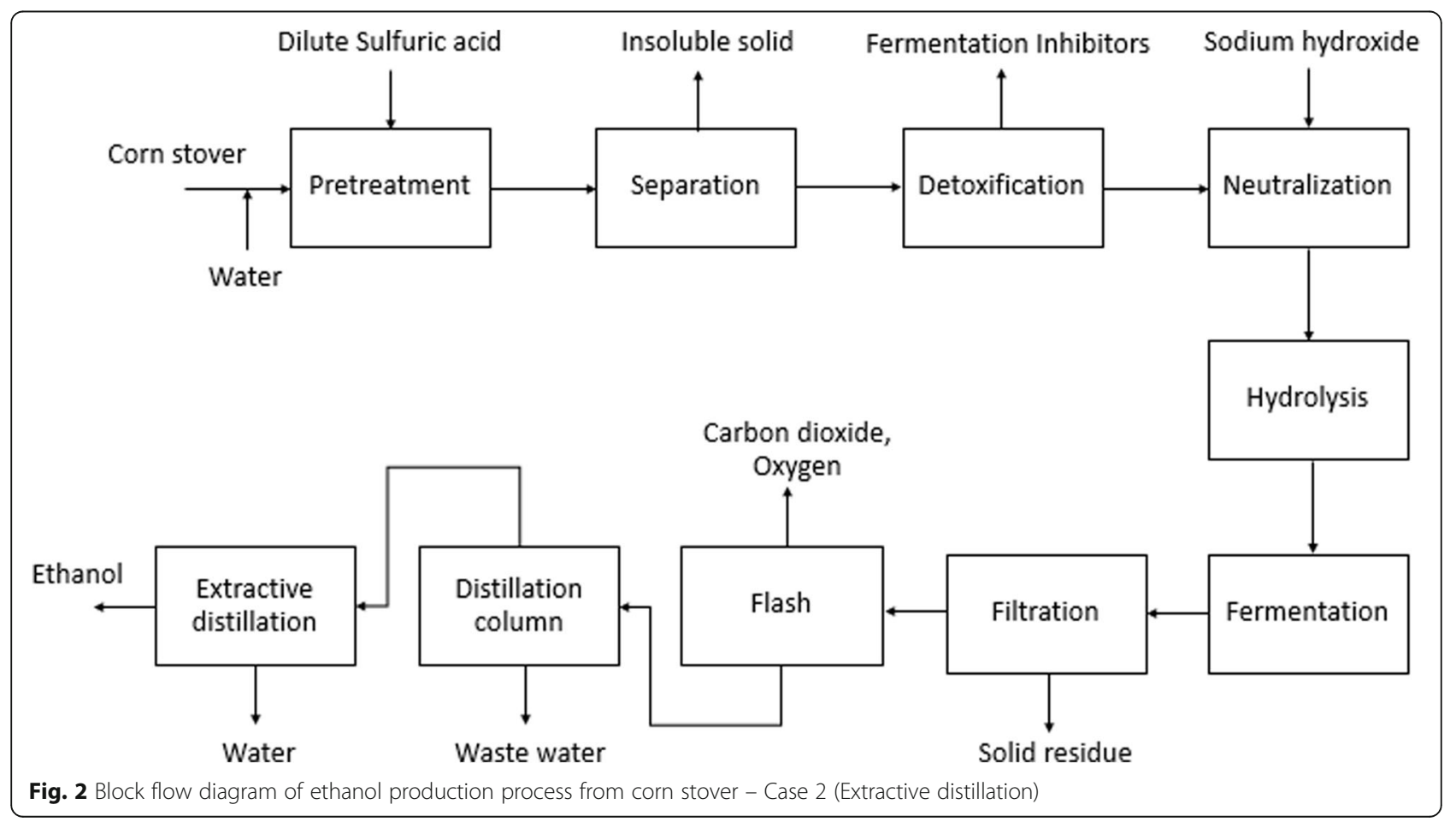




\section{Alternative process}

The production process of ethanol from corn stover begins with the pretreatment of corn stover by using dilute sulfuric acid. After that, it is followed by a solid/liquid separator to remove insoluble solids in the feed. Before entering the hydrolysis, it is vital to remove fermentation inhibitors from the feed, and this step is called detoxification. It was found that using activated carbon is a very effective method as it can remove 93\% of furfural and 96\% of 5-hydroxymethyl furfural (HMF), and, more importantly, without sugar loss $[25,36]$. Hence, it is used in our design cases 2 and 3 . After the inhibitors are removed, the corn stover feed is sent to a neutralization unit to adjust the $\mathrm{pH}$ to a suitable condition. Then, it is passed to the hydrolysis and fermentation to convert cellulose into fermentable sugars and ethanol, respectively. After the fermentation, the fermentation broth is sent to filtration to remove the suspended solids present in the fermentation broth. Then, it is followed by a flash operation to remove most of the dissolved $\mathrm{CO}_{2}$ at low temperatures. After that, the liquid product is sent to the distillation column to concentrate the ethanol to near azeotrope. In the last step, the dehydration, the concentrated ethanol is purified by pervaporation [37] to produce anhydrous ethanol (case 3). Alternatively, extractive distillation using ethylene glycol as a solvent [14] is investigated (case 2 ). Block flow diagrams of the ethanol production process from corn stover for both cases are illustrated in Figs. 2 and 3.
It should be noted that the pervaporation model used in this work was based on the work by Hafrat et al. [16] since there is no pervaporation model available in the Aspen Plus software. Thus, a calculator block using a built-in Fortran code was created in Aspen Plus to simulate the pervaporation model. In principle, the diffusion passing through the membrane depends on the concentration of retentate and permeate, as shown in Eq. 22.

$$
\Phi_{j}=D_{i}\left(C_{R j}-C_{P j}\right)
$$

Where $\Phi_{j}$ is a molar flux of component $\mathrm{j}, D_{j}$ is the diffusivity of component $j, C_{R j}$ is the concentration of component $j$ in the liquid retentate, and $C_{P j}$ is the concentration of component $j$ in the steam permeate.

The concentration of component $j$ in the liquid retentate and concentration of component $j$ in the vapor permeate are calculated by Eqs. 23 and 24, respectively.

$$
C_{R j}=\frac{\rho_{p}}{M_{i}} w_{R j}
$$

Where $C_{R j}$ is the concentration of component $j$ in the liquid retentate, $\rho_{p}$ is the density of the liquid permeate $\left(\mathrm{kg} / \mathrm{m}^{3}\right), M_{i}$ is the molecular weight of component $j(\mathrm{~kg} /$ $\mathrm{kmol}), w_{R i}$ is the mass fraction of compound $j$ in the liquid retentate.

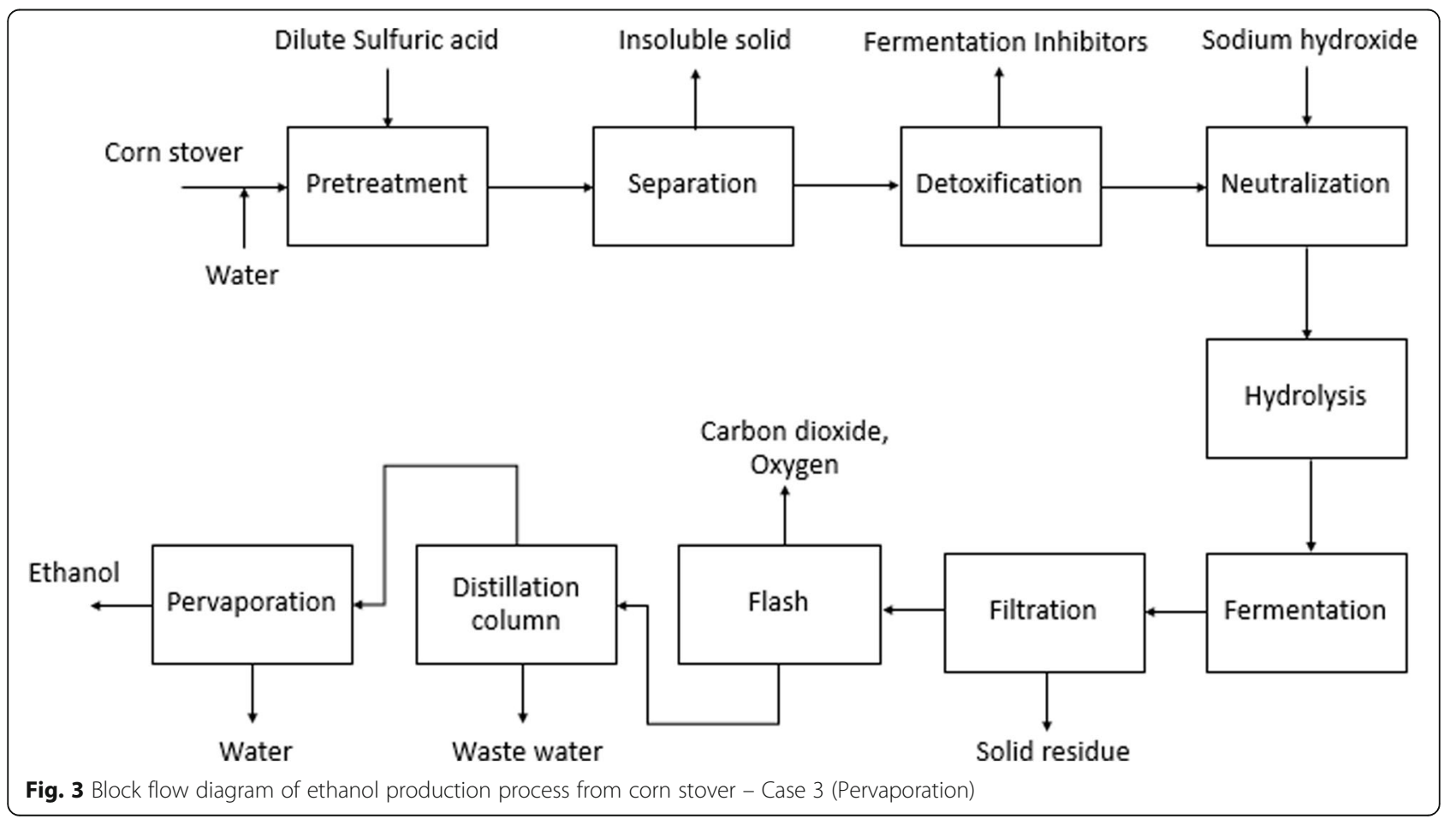




$$
C_{P j}=\frac{P_{p}}{R T_{P}} z_{P j}
$$

Where $C_{p j}$ is the concentration of component $j$ in the vapor permeate, $P_{p}$ is the pressure of the permeate through the membrane (atm), $z_{P j}$ is the mole fraction of compound $j$ in the permeate, $T$ is temperature (K), $R$ is the ideal gas constant $(R=0.08206 \mathrm{~L}-\mathrm{atm} / \mathrm{mol}-\mathrm{K})$.

The coefficients of diffusivity for ethanol and water, modified from Yeom and Huang [38], are obtained by Eqs. 25 and 26, respectively.

$$
\begin{gathered}
D_{\text {ethanol }}=2.028 \times 10^{6} e^{\frac{-9385}{T}} \\
D_{\text {water }}=1.158 \times 10^{9} e^{\frac{-9385}{T}}
\end{gathered}
$$

\section{Process evaluation}

Sustainability of a process is determined by multiple criteria, i.e., energy consumption, process economics, and environmental impacts. Economics of the bioethanol production processes in this research is carried out based on Method of Guthrie, which consists of capital investment cost (such as fixed capital cost and working capital cost), total production cost (such as manufacturing cost and general expense) [21]. For the impacts on the environment, life cycle assessment (LCA) is used as a method to evaluate environmental impacts associated with all the stages of a product's life. For example, Kusolsongtawee et al. [39] evaluated the environmental impact of the bioethanol production process from Ceratophyllum demersum in terms of carbon footprint. This research analyzes the LCA by using LCSoft software that is developed based on LCA methodology by Kalakul et al. [26]. The software can estimate the impact of a chemical process on the environment by using some input data, including energy consumption of each unit operation, type of energy sources, type of raw materials, amount of mass input, and amount of mass output. The main result obtained from the software is presented in terms of carbon footprint $\left(\mathrm{CO}_{2}\right.$ eq.). Several other environmental impacts are also estimated, which are human toxicity potential from ingestion and inhalation (HTPI), human toxicity

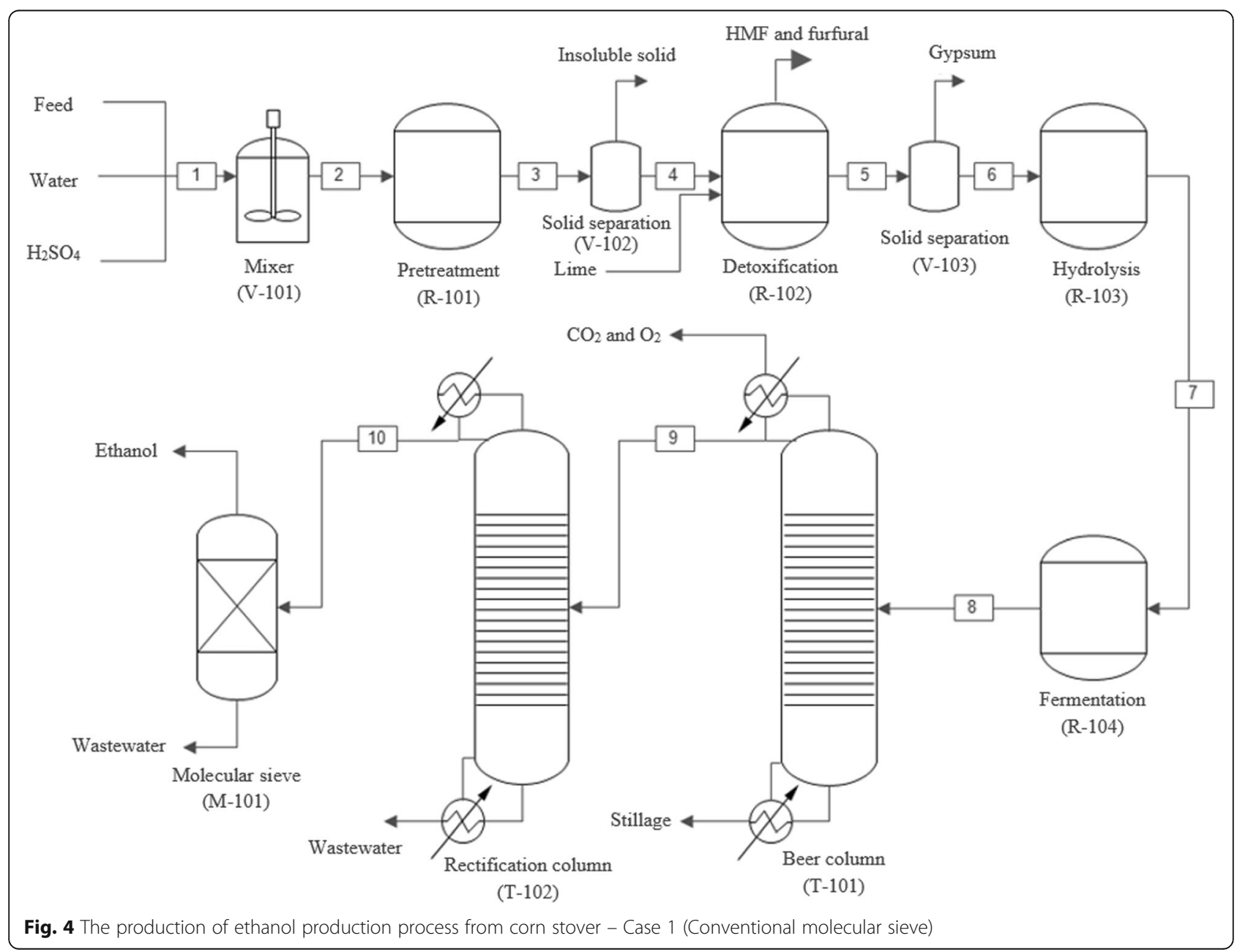


potential from dermal exposure (HTPE), aquatic toxic potential (ATP), Global warming potential (GWP), ozone depletion potential (ODP), photochemical oxidation potential (PCOP), Acidification potential (AP), Human toxicity carcinogens (HTC), human toxicity noncarcinogenic impact (HTNC), and ecotoxicological potential (ET) [22]. Noted that the system boundary used in this work was gate-to-gate. Thus, plantation, transportation, and waste treatment are not mentioned.

\section{Results and discussion}

The ethanol production from corn stover with three different separation processes was designed and simulated by using Aspen plus software. Process flowsheets of the three processes are shown in Figs. 4, 5 and 6. The operating conditions used for each unit are summarized and shown in Tables 2 and 3. In the next step, we analyze and compare the processes in terms of energy consumption, process economics, and environmental impacts.

\section{Energy consumption}

The results of energy consumptions consisting of heating and cooling of the three processes are represented in the form of heat duty. They are summarized and shown in Fig. 7. The energy consumption of each unit is also provided in Table 4. For the reaction section, the energy consumptions of the three cases are not much different. Furthermore, they are relatively much smaller compared to energy usage in the separation section. However, cases 2 and 3 were found to consume less energy than case 1 as a result of using activated carbon for the detoxification in place of the over-liming method. Nevertheless, the saving is not substantial and may even be neglected if we compare it with the total energy saving.

For the separation section, the energy consumption in case 1 is much higher than the energy consumption in cases 2 and 3 . The reason is that the binary adjacent ratio of properties between ethanol and water of the molecular sieve is lower that of extractive distillation and pervaporation. Therefore, case 1 requires the Beer column and rectification column to handle the ethanol separation before sending the ethanol to the molecular sieve. Moreover, because the relative volatility between water and ethanol is closed to 1, azeotrope between ethanol and water is formed. It leads to a high reflux ratio of the columns

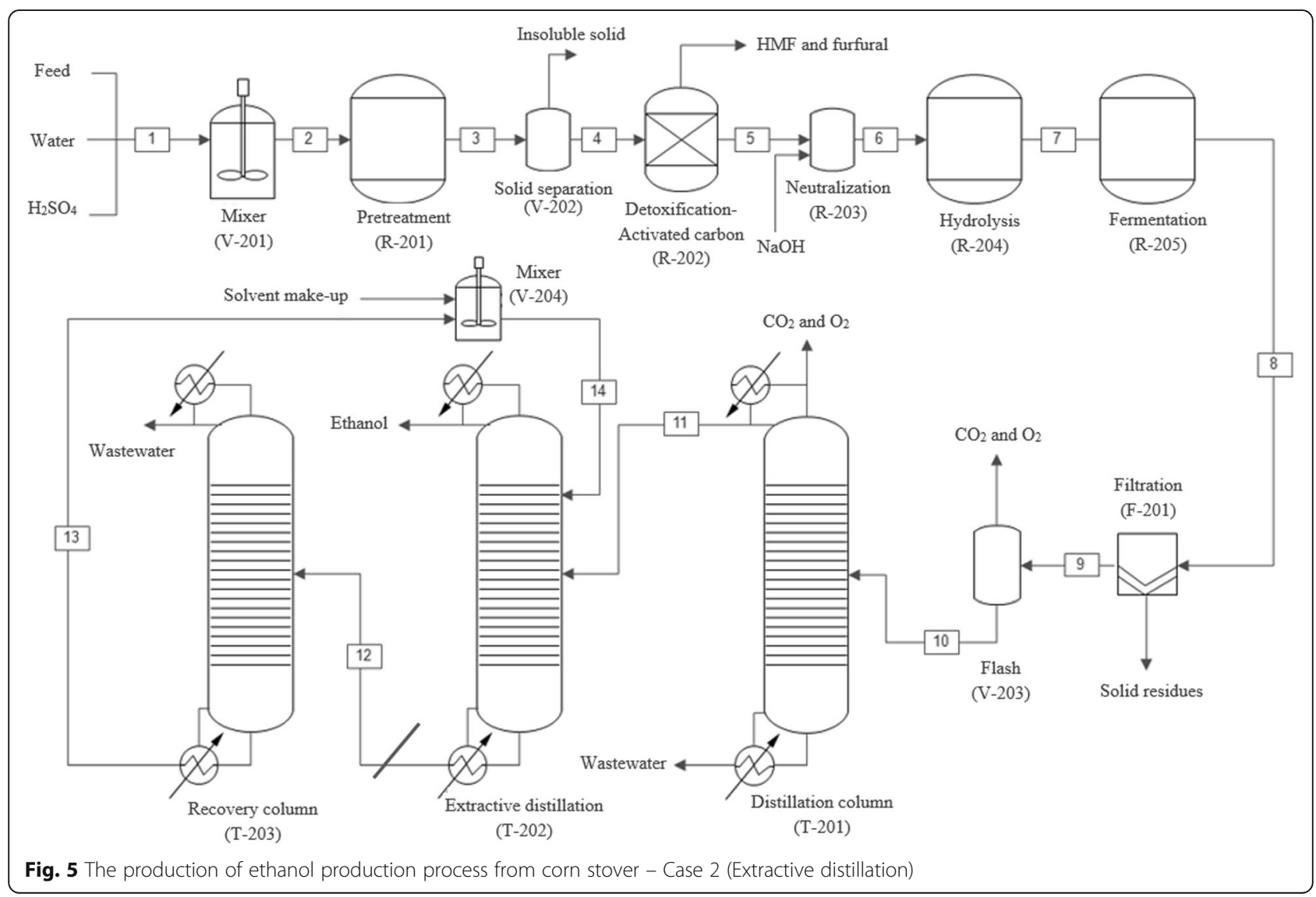




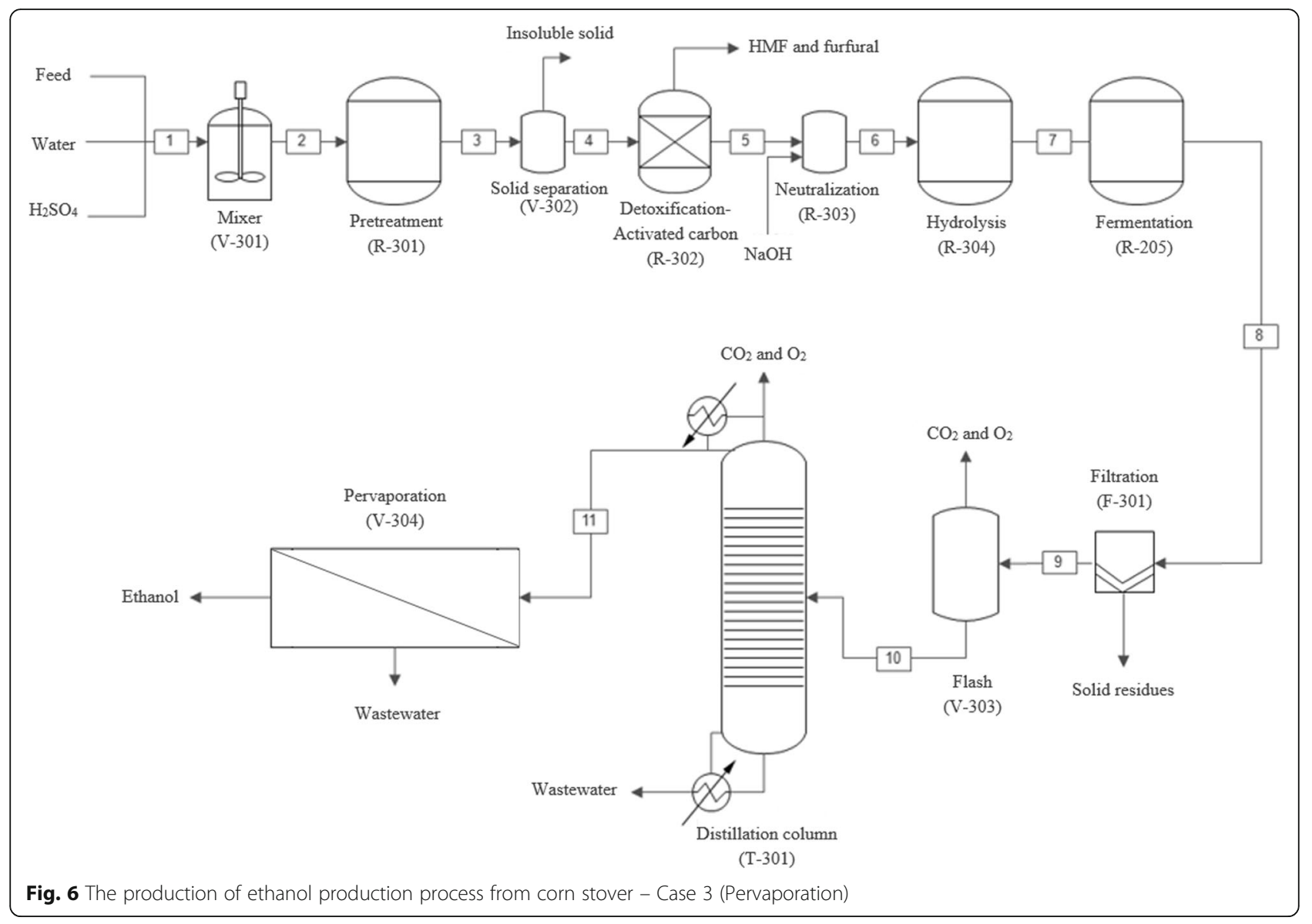

Table 2 The condition in the reactor and the separation process

\begin{tabular}{ll}
\hline Type & Condition \\
\hline Pretreatment & Type: Dilute acid \\
& Agent: $\mathrm{H}_{2} \mathrm{SO}_{4}$ \\
& Acid loading: $18 \mathrm{mg} / \mathrm{g}$ biomass \\
& Temperature: $158^{\circ} \mathrm{C}$ \\
& Pressure: $5.5 \mathrm{~atm}$ \\
Hydrolysis & Temperature: $48^{\circ} \mathrm{C}$ \\
& Pressure: 1 atm \\
Fermentation & Agent: $z$. mobilis bacterium \\
& Temperature: $32^{\circ} \mathrm{C}$ \\
Beer column & Pressure: 1 atm \\
& Number of stages: 32 \\
& Feed on stages: 4 \\
Rectification column & Reflux ratio: 3 \\
Number of stages: 15 & Feed on stages: 7 \\
& Reflux ratio: 2.5 \\
& Distillate rate: $530 \mathrm{kmol} / \mathrm{hr}$ \\
\hline
\end{tabular}

and thus a high heat duty. From this viewpoint, the distillation columns followed by the molecular sieve is not a suitable separation process in terms of energy consumption. On the other hand, from the binary ratio, the molar volume gives the highest ratio in comparison with other properties. It indicates that the pervaporation would provide the highest driving force for the separation. The results confirmed that case 3 is the most appropriate process as its energy consumption is the lowest.

Specific energy consumption, defined as the ratio of the energy required per liter of ethanol produced, is determined. It was found that the specific energy consumptions of case 1, 2, and 3 are 4599, 2352, and 2197 BTU/liter, respectively. It can be seen that both cases 2 and 3 are much more attractive than case 1 in terms of energy efficiency. Since the energy consumptions for the reaction section are not much different, the high energysaving for cases 2 and 3 were obtained from the separation section. To sum up, from the energy efficiency's viewpoint, case 3 is more efficient for ethanol separation. It is also interesting to consider ethanol recovery from different separation processes. Therefore, the ratios of ethanol product to ethanol feed to the separation section 
Table 3 Operating conditions of equipment

\begin{tabular}{|c|c|c|}
\hline Equipment & Parameters & Operating conditions \\
\hline \multirow[t]{4}{*}{ Distillation (case 1) } & Reflux ratio & 2.5 \\
\hline & Distillate rate & $530 \mathrm{kmol} / \mathrm{hr}$ \\
\hline & Number of stage & 15 \\
\hline & Feed stage & 7 \\
\hline \multirow[t]{2}{*}{ Flash (case 2,3) } & Temperature & $32^{\circ} \mathrm{C}$ \\
\hline & Pressure & $1 \mathrm{bar}$ \\
\hline \multirow[t]{7}{*}{ Extractive distillation (case 2) } & Reflux ratio & 1 \\
\hline & Distillate rate & $445 \mathrm{kmol} / \mathrm{hr}$ \\
\hline & Number of stage & 12 \\
\hline & Feed stage of crude ethanol & 8 \\
\hline & Feed stage of solvent & 4 \\
\hline & Solvent & Ethylene glycol \\
\hline & Ratio of solvent to feed & 2 \\
\hline \multirow[t]{4}{*}{ Recovery column (case 2) } & Reflux ratio & 1 \\
\hline & Distillate rate & $82 \mathrm{kmol} / \mathrm{hr}$ \\
\hline & Number of stage & 9 \\
\hline & Feed stage & 4 \\
\hline \multirow[t]{2}{*}{ Pervaporation (case 3) } & Temperature & $129^{\circ} \mathrm{C}$ \\
\hline & Area of membrane & $1950 \mathrm{~m}^{2}$ \\
\hline
\end{tabular}

of the three cases were also determined and found to be $0.64,0.77$, and 0.74 , respectively. These results also support that case 2 and 3 are more efficient processes as the ethanol recovery for both cases are significantly higher than the ethanol recovery of case 1 . It can be noticed that the ethanol recovery of case 2 is slightly higher than case 3, even though its energy efficiency is slightly lower.
To justify which case is more suitable, process economics and environmental impacts need to be considered further.

\section{Economic analysis}

The total capital investment costs of the three cases are illustrated in Fig. 8. It can be seen that the total capital

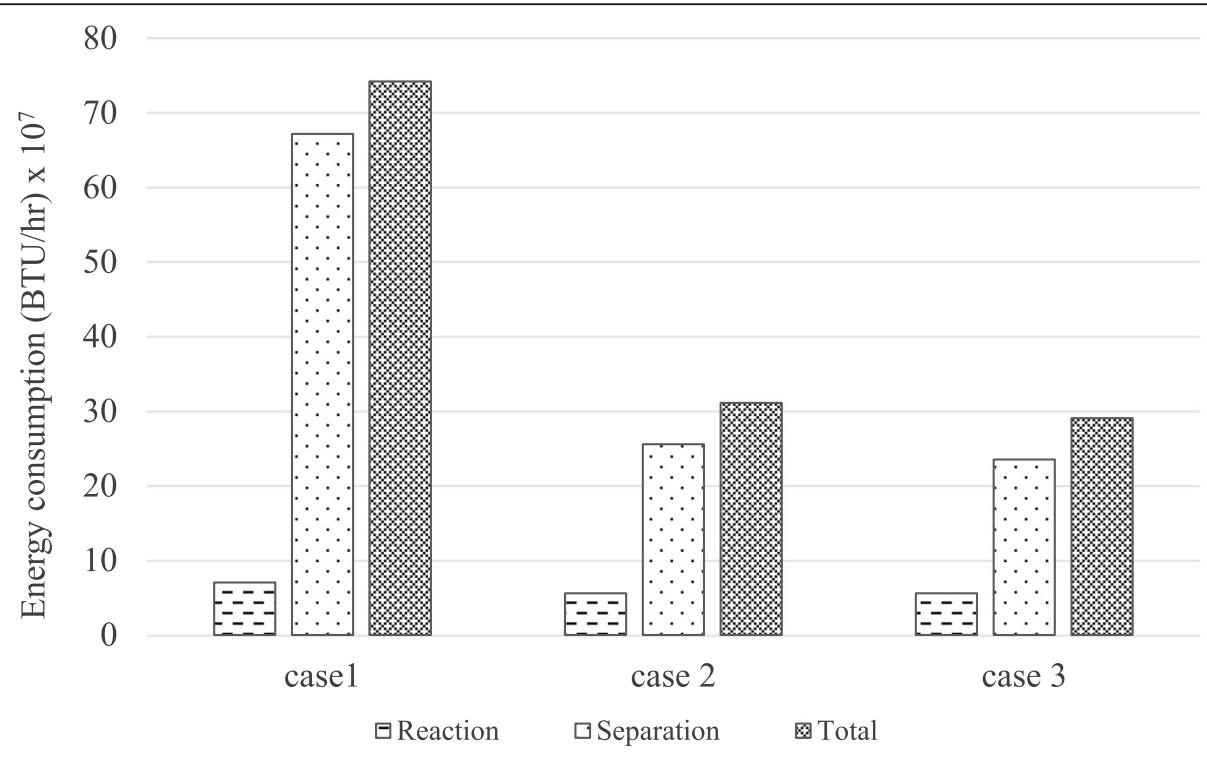

Fig. 7 Energy consumption used in reaction and separation sections of different ethanol production processes 
Table 4 Energy consumption of each unit

\begin{tabular}{|c|c|c|c|}
\hline \multirow[t]{2}{*}{ Unit } & \multicolumn{3}{|c|}{ Energy consumption (BTU/hr) } \\
\hline & Case 1 (base case) & Case 2 & Case 3 \\
\hline Pretreatment & $1.47 \times 10^{7}$ & $1.47 \times 10^{7}$ & $1.47 \times 10^{7}$ \\
\hline Sep-01 & $1.29 \times 10^{4}$ & $1.29 \times 10^{4}$ & $1.29 \times 10^{4}$ \\
\hline DETOX & $1.92 \times 10^{7}$ & $1.92 \times 10^{7}$ & $1.92 \times 10^{7}$ \\
\hline De-TOXIC & $2.36 \times 10^{3}$ & - & - \\
\hline Hydrolysis & $1.34 \times 10^{7}$ & $1.93 \times 10^{7}$ & $1.93 \times 10^{7}$ \\
\hline Fermentation & $2.29 \times 10^{7}$ & $2.40 \times 10^{6}$ & $2.40 \times 10^{6}$ \\
\hline Beer column-condenser & $1.94 \times 10^{8}$ & - & - \\
\hline Beer column-reboiler & $1.92 \times 10^{8}$ & - & - \\
\hline Rectification column-condenser & $1.27 \times 10^{8}$ & - & - \\
\hline Rectification column-reboiler & $1.27 \times 10^{8}$ & - & - \\
\hline Molecular sieve & $3.16 \times 10^{7}$ & - & - \\
\hline DETOC-AC & - & $1.05 \times 10^{5}$ & $1.05 \times 10^{5}$ \\
\hline Filtration & - & $1.97 \times 10^{6}$ & $1.97 \times 10^{6}$ \\
\hline Flash & - & $8.81 \times 10^{-8}$ & $8.81 \times 10^{-8}$ \\
\hline Distillation column-condenser & - & $7.54 \times 10^{7}$ & - \\
\hline Distillation column-reboiler & - & $7.70 \times 10^{7}$ & - \\
\hline Extractive distillation-condenser & - & $3.71 \times 10^{7}$ & - \\
\hline Extractive distillation-reboiler & & $4.69 \times 10^{7}$ & \\
\hline Recovery column-condenser & & $6.56 \times 10^{6}$ & \\
\hline Recovery column-reboiler & & $1.06 \times 10^{7}$ & \\
\hline Pervaporation & & & $2.33 \times 10^{8}$ \\
\hline
\end{tabular}

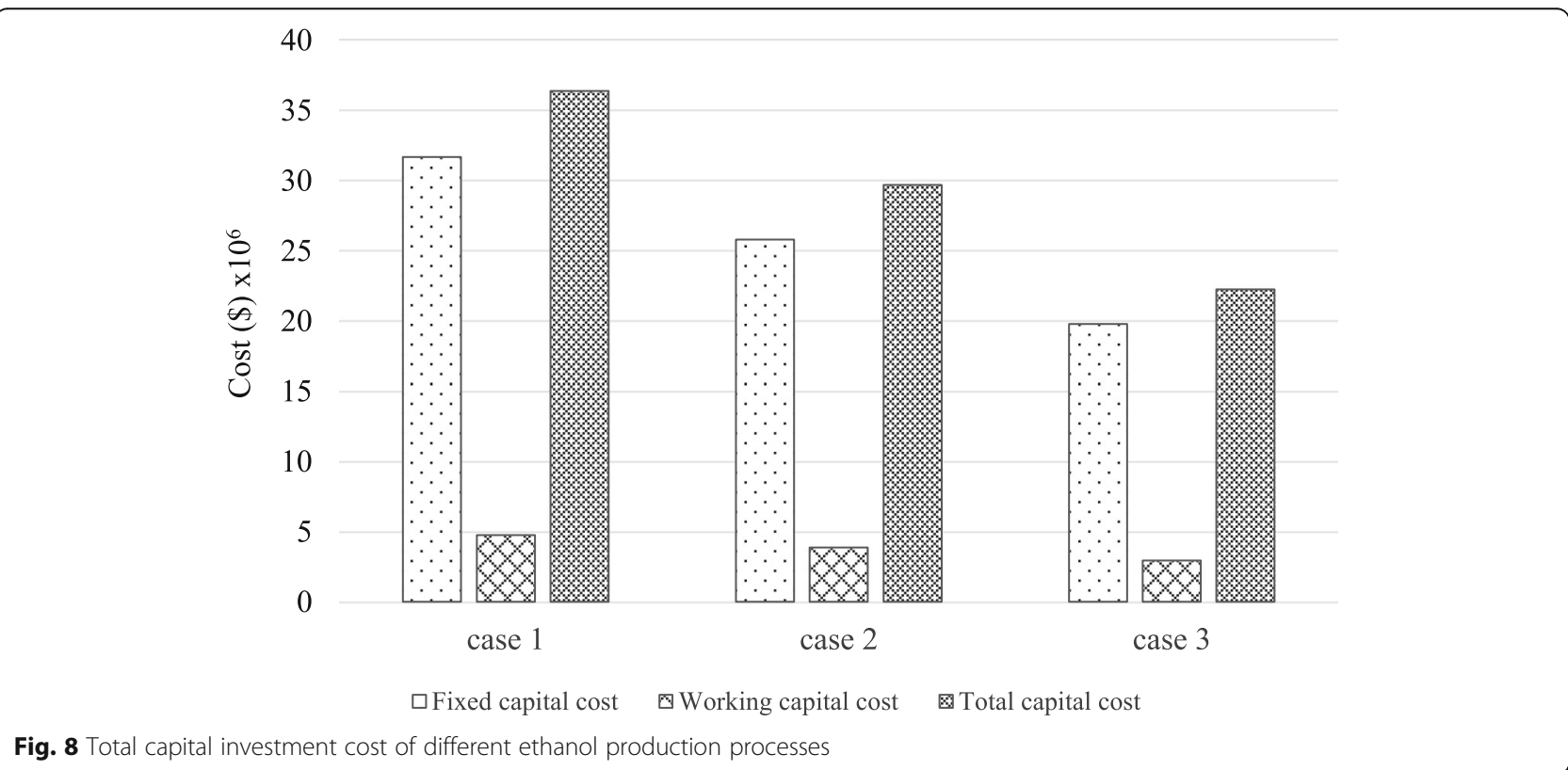

Fig. 8 Total capital investment cost of different ethanol production processes 
investment cost of cases 2 and 3 are lower than the cost of case 1. The main reason is the use of filtration and flash separator to remove to some suspended solids and gaseous components from the fermentation broth before using the distillation column. In case 1, the Beer column is used to perform these two tasks as well as to separate ethanol. Since the column has to perform several tasks simultaneously, its sizing, together with the sizing of subsequent rectification column, are inevitably large. The large sizing of Beer column and rectification column therefore resulted in very high total investment cost. Compared with case 3, case 2 uses the extractive distillation to purify the ethanol. This method, by nature, requires a high investment cost, too. Thus, it is unsurprising that case 3 has the lowest total investment cost among all, at $2.27 \times 10^{7} \$$.

The total production costs of the three cases, including direct production costs and fixed charges, are illustrated in Fig. 9. Direct production costs include raw materials, utilities, and other costs (i.e., the sum of labor, catalyst and solvent, maintenance and repair, and insurance). The prices of raw material and utilities are shown in Table 5. Fixed charge costs consist of depreciation, local taxes, and laboratory analysis. From the figure, it can be noticed that the raw material cost is the most significant factor of the total production cost as it contributes to the significant part of the cost. The economic calculation revealed that direct production costs contribute to $98-99 \%$ of the total production cost. In general, it can be seen that case 1 has the highest total production cost, mainly due to its high raw material and utility consumptions.
Table 5 Price of chemicals and utilities

\begin{tabular}{lll}
\hline Components & Price & References \\
\hline Corn stover & $59(\$ /$ ton $)$ & {$[7]$} \\
Sulfuric acid & $250(\$ /$ ton $)$ & {$[40]$} \\
Sodium hydroxide & $300(\$ /$ ton $)$ & {$[41]$} \\
Lime & $330(\$ /$ ton $)$ & {$[41]$} \\
Ethanol & $1.3(\$ /$ gallon $)$ & {$[42]$} \\
Ethylene glycol & $1610(\$ /$ ton $)$ & {$[43]$} \\
Steam cost & $4 \$ / 1000$ gal & {$[44]$} \\
Cooling cost & $0.05 \$ / 1000 \mathrm{gal}$ & {$[45]$} \\
\hline
\end{tabular}

The reason that case 1 has a higher raw material cost is that about $10 \%$ of sugar loss occurred during the detoxification. This loss caused an increase in the required amount of raw materials. For the utility consumption, case 1 consumed very high utilities because the sizings of the Beer column and rectification column are very large, to be able to handle the large volume of feed. Hence, the heating (steam) and cooling energy required to operate the reboilers and condensers of the columns are consequently very high too. The total production cost of case 2 was found to be slightly higher than in case 3 . It is because case 2 uses the extraction distillation and recovery column for ethanol purification. So, there is a need for solvent and higher utilities for the columns' operation. It can be concluded that case 3 is the most economical process with the lowest total production cost of $5.39 \times 10^{8}$ \$.

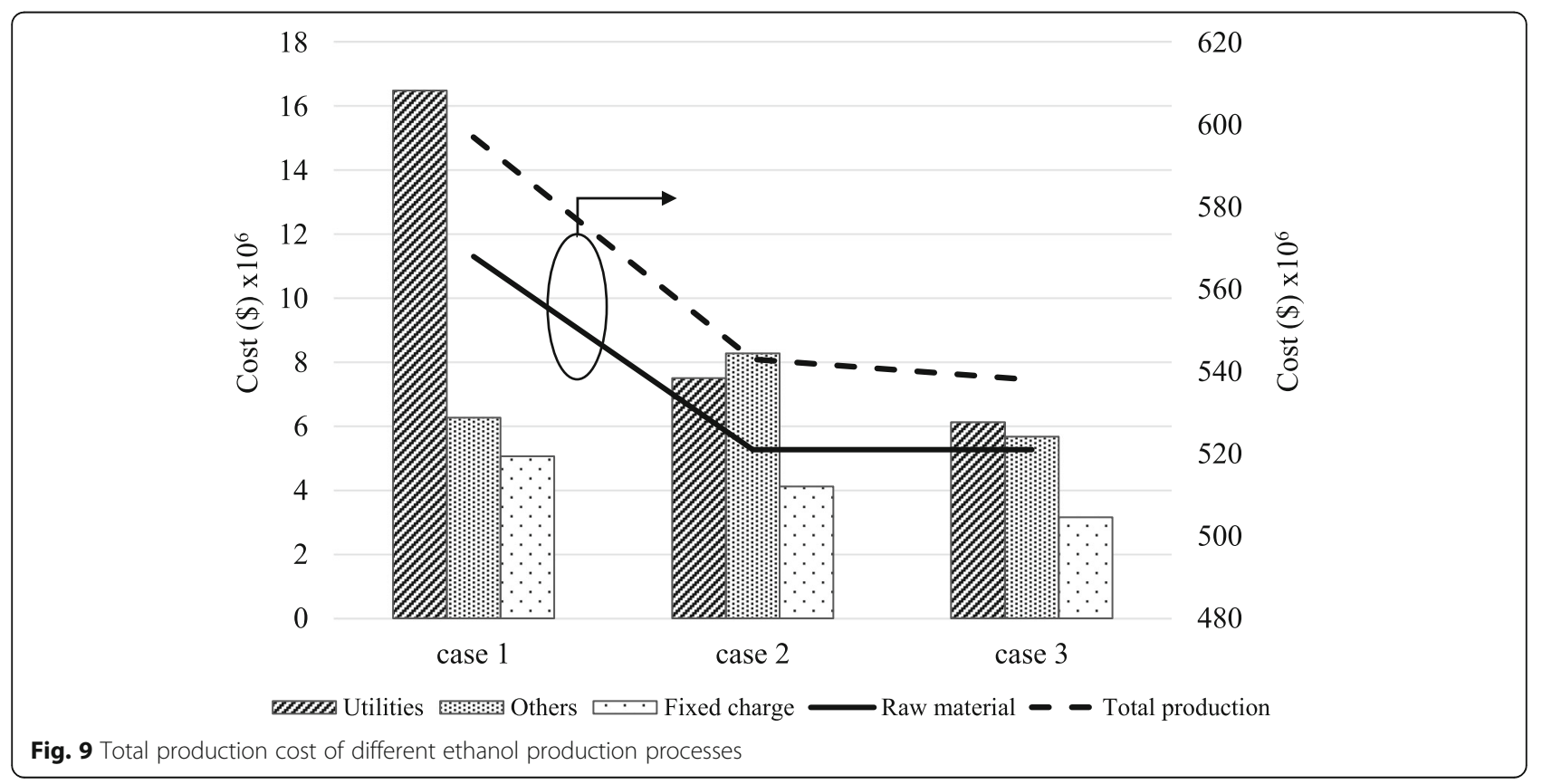




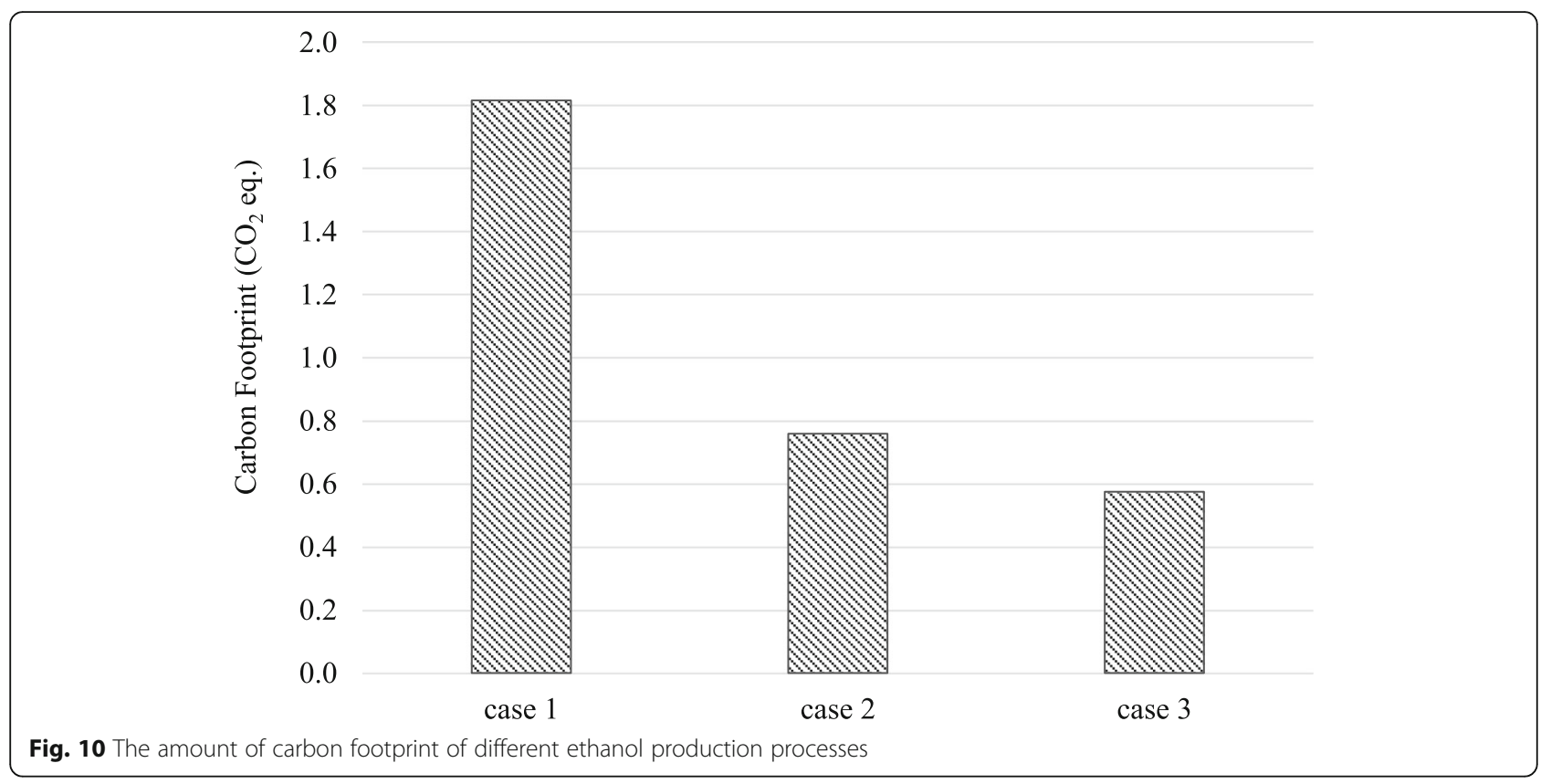

\section{Environmental impact}

It is widely accepted that carbon footprint can be used as a key parameter that represents the impact of a process on the environment. It is generally generated by the combustion of fuel, such as natural gas used to produce utilities required for the process. Such combustion is, for example, steam production in a boiler or chilled water production through an absorption chiller. The amounts of the carbon footprint of the three processes were shown in Fig. 10. The results reveal that case 1 releases the highest amount of carbon footprint, at $1.816 \mathrm{CO}_{2}$ eq. It is a direct consequence of using the high amount of utilities in the Beer column and rectifying column. The carbon footprint in case 3 was found to be the lowest, at $0.575 \mathrm{CO}_{2}$ eq. It is mostly generated from the distillation column (T-301) that separates wastewater.

The comparisons of other environmental impact indicators of the three cases were summarized and illustrated in Figs. 11, 12 and 13. They are HTPI (1/LD 50), HTPE (1/TWA), ATP (1/LC 50), GWP ( $\mathrm{CO}_{2}$ equivalent), ODP (CFC-11 equivalent), PCOP $\left(\mathrm{C}_{2} \mathrm{H}_{2}\right.$ equivalent), AP ( $\mathrm{H}^{+}$equivalent), $\mathrm{HTC}$ ( $\mathrm{kg}$ of benzene equivalent), HTNC ( $\mathrm{kg}$ toluene equivalent), and ET ( $\mathrm{kg} \mathrm{2,4-dichlorophenoxyacetic} \mathrm{acid}$ equivalent). Overall, it can be concluded that case 3 is the most environmentally friendly process as it

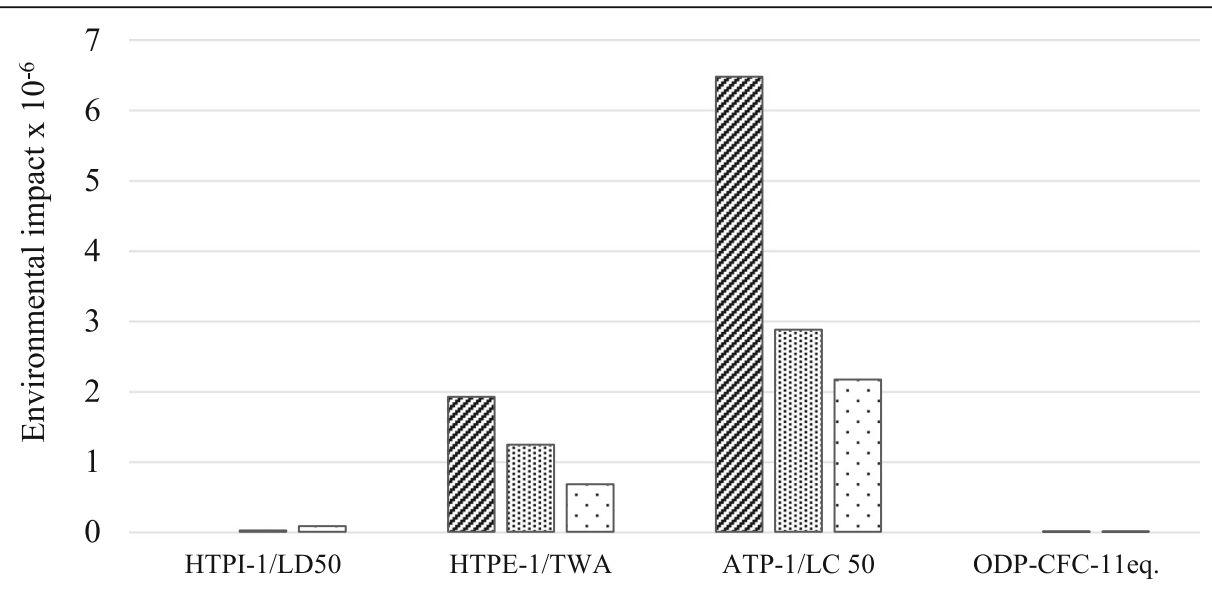

$\square$ case 1 䒠 case $2 \quad \square$ case 3

Fig. $11 \mathrm{HTPI}$ (1/LD 50), HTPE (1/TWA), ATP (1/LC 50), and ODP (CFC-11 equivalent) of different ethanol production processes 


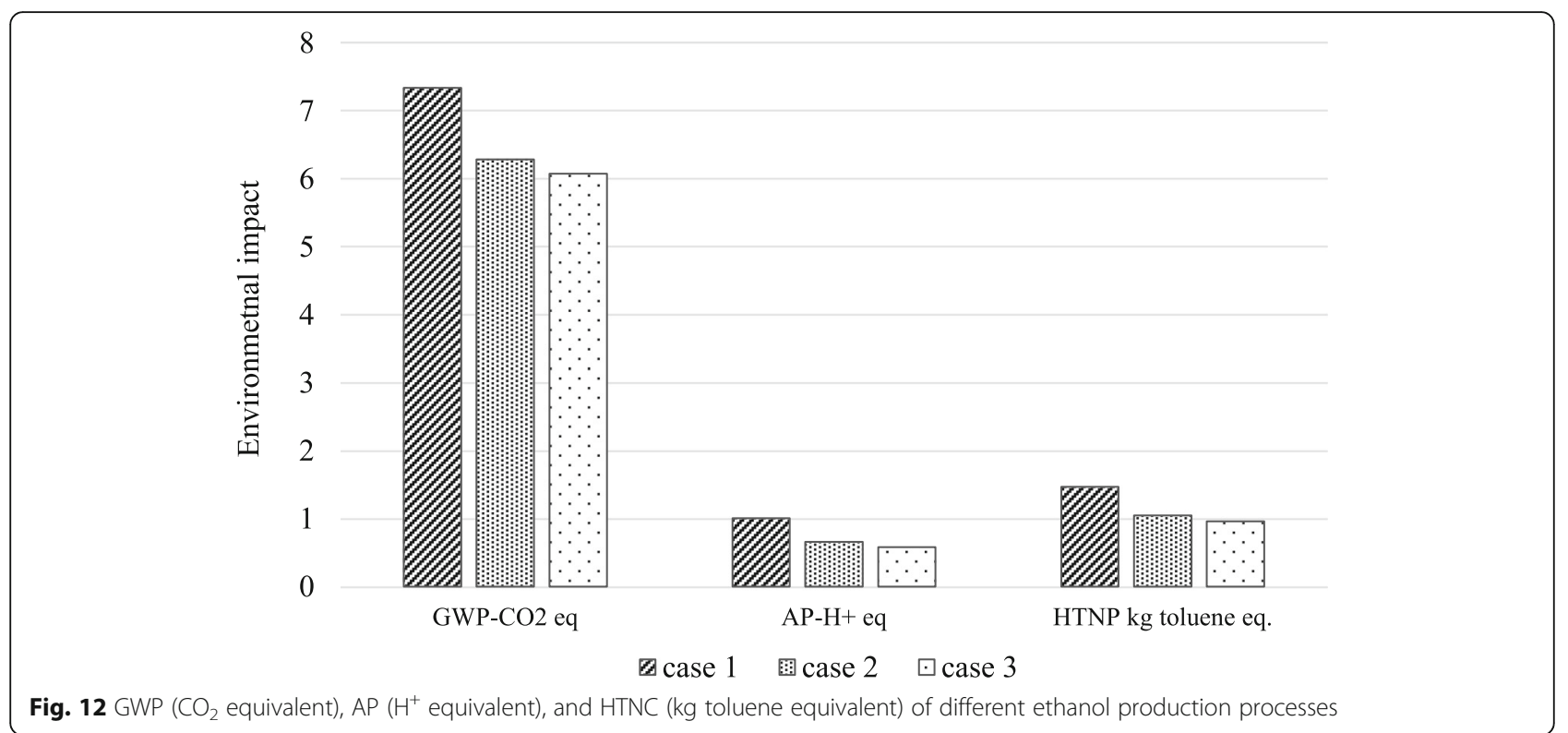

has the lowest environmental impacts for most categories.

\section{Conclusion}

Guided by thermodynamic insight, extractive distillation (case 2) and pervaporation (case 3) were obtained as alternative separation processes for ethanol production from corn stover. Their performances were investigated in terms of energy consumption, economic analysis, and environmental impacts and compared with conventional molecular sieve (case 1). It was revealed that the pervaporation (case 3) is the best separation process. Compared to case 1 and case 2 , the total energy used by case
3 is 60.8 and $6.6 \%$ lower, while the carbon footprint generated is 68.3 and $24.2 \%$ lower, respectively. The design of the pervaporation process is less complicated than the other cases, resulting in the lowest total capital cost and total production cost.

Even though pervaporation was found to be the best separation process, more works can be done to improve the process performance. One potential improvement is to recover the ethanol loss to wastewater at the pervaporation. It may be done by installing a distillation column to separate water from the wastewater and send back the concentrated ethanol to the pervaporator to recover more ethanol.

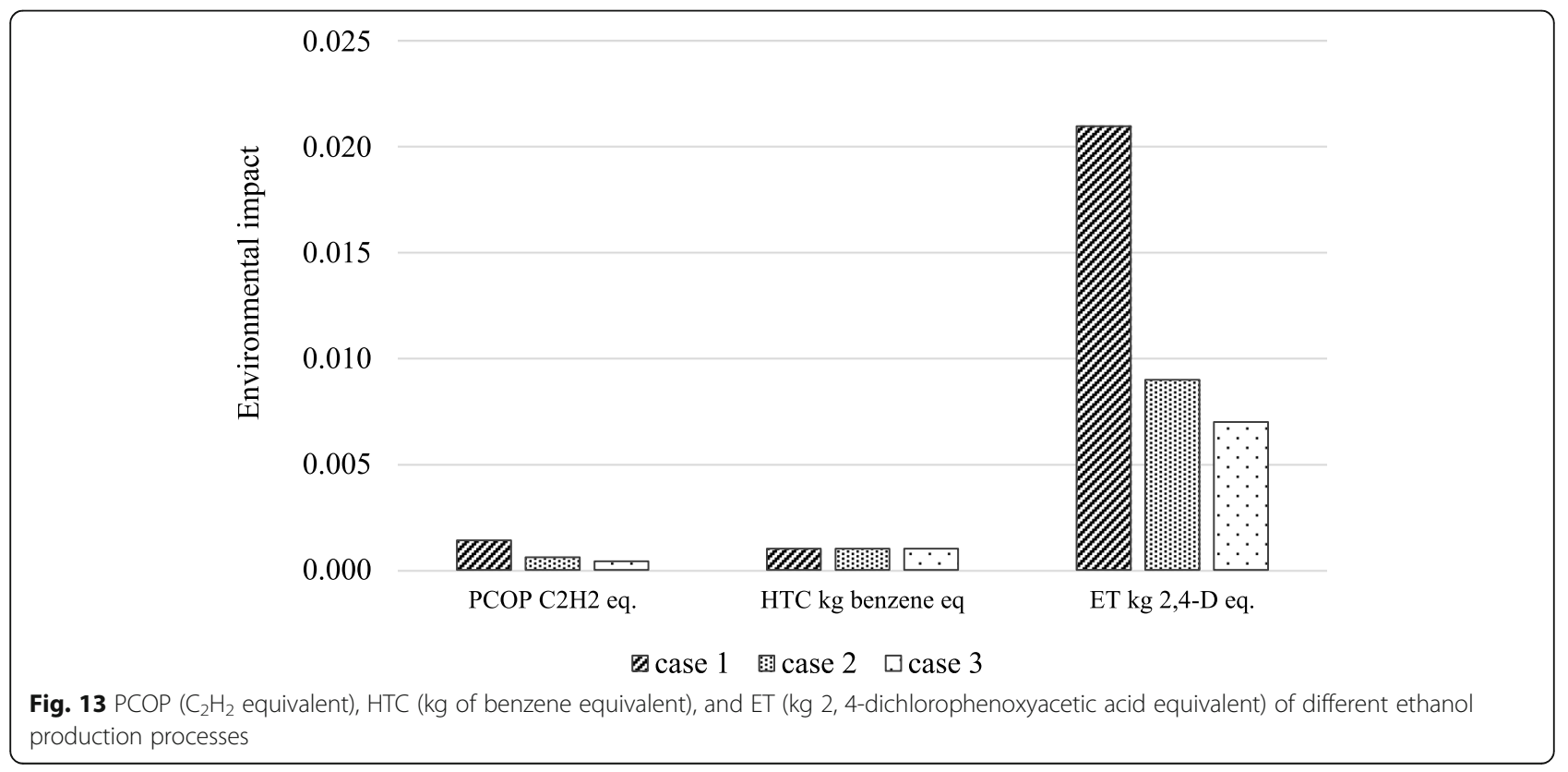




\section{Supplementary information}

Supplementary information accompanies this paper at https://doi.org/10. 1186/s42480-020-00033-1.

Additional file 1. Systematic design of separation process for bioethanol production from corn stover.

\section{Abbreviations}

AHP: Analytical hierarchy process; AP: Acidification potential ( $\mathrm{H}+$ equivalent); ATP: Aquatic toxic potential (1/LC 50); ET: Eco-toxicological potential (kg 2,4dichlorophenoxyacetic acid equivalent); LCA: Life cycle assessment; HMF: Hydroxymethyl furfural; HTC: Human toxicity carcinogens (kg of benzene equivalent); NRTL: Non-random two-liquid; GWP: Global warming potential $\left(\mathrm{CO}_{2}\right.$ equivalent); HTNC: Human toxicity noncarcinogenic impacts (kg toluene equivalent); HTPI: Human toxicity potential from ingestion and inhalation (1/LD 50); HTPE: Human toxicity potential from dermal exposure (1/TWA); ODP: Ozone depletion potential (CFC-11 equivalent); PCOP: Photochemical oxidation or smog formation potential $\left(\mathrm{C}_{2} \mathrm{H} 2\right.$ equivalent)

\section{Acknowledgements}

The authors would like to give special thanks to PSE for SPEED Company Limited for providing LCSoft program for use in this work. S. Assabumrungrat would like to acknowledge the "Research Chair Grant" National Science and Technology Development Agency (NSTDA).

\section{Authors' contributions}

SAM: Conceptualization, Methodology, Supervision, Writing - Original. IS: Methodology, Investigation, Software, Writing - Review \& Editing. LS: Conceptualization, Writing - Review \& Editing. SAS: Writing - Review \& Editing. All authors have read and approved the manuscript.

\section{Funding}

This research was funded by King Mongkut's University of Technology North Bangkok, Contract no. KMUTNB-GOV-56-13. The funder only provided financial support to SA and IS to produce this research work. They did not take part in any work process of this research.

\section{Availability of data and materials}

The datasets used and/or analysed during the current study are available from the corresponding author on reasonable request.

\section{Competing interests}

The authors declare that they have no competing interests.

\section{Author details}

${ }^{1}$ Chemical and Process Engineering Program, The Sirindhorn International Thai-German Graduate School of Engineering (TGGS), King Mongkut's University of Technology North Bangkok, Bangkok 10800, Thailand. ${ }^{2}$ Department of Industrial Chemistry, Faculty of Applied Science, King Mongkut's University of Technology North Bangkok, Bangkok 10800, Thailand. ${ }^{3}$ Center of Excellence in Catalysis and Catalytic Reaction Engineering, Department of Chemical Engineering, Faculty of Engineering, Chulalongkorn University, Bangkok, Thailand.

\section{Received: 6 December 2019 Accepted: 16 September 2020}

\section{Published online: 12 October 2020}

\section{References}

1. Naik SN, Goud W, Rout PK, Dalai AK. Production of first and second generation biofuels: a comprehensive review. Renew Sust Energ Rev. 2010; 14:578-97.

2. Dias MOS, Junqueira $T L$, Jesus CDF, Rossell CEV, Filho RM, Bonomi A. Improving second generation ethanol production through optimization of first generation production process from sugarcane. Energy. 2012;43:246-52

3. Zhao J, Xia L. Ethanol production from corn stover hemicellulosic hydrolysate using immobilized recombinant yeast cells. Biochem Eng J. 2010;49:28-32

4. Balata M, Balata $\mathrm{H}, \mathrm{Oz}$ C. Progress in bioethanol processing. Prog Energy Combust Sci. 2008;34:551-73.
5. Lavaracka BP, Griffin GJ, Rodman D. The acid hydrolysis of sugarcane bagasse hemicellulose to produce xylose, arabinose, glucose and other products. Biomass Bioenergy. 2002;23(5):367-80.

6. Gírio FM, Fonseca C, Carvalheiro F, Duarte LC, Marques S, Bogel-Łukasik R. Hemicelluloses for fuel ethanol: a review. Bioresour Technol. 2010;101(13): 4775-800.

7. Humbird D, Davis R, Tao L, Kinchin C, Hsu D, Aden A. Process design and economics for biochemical conversion of lignocellulosic biomass to ethanol. Colorado: National Renewable Energy Laboratory; 2011.

8. Tgarguifa A, Abderafi S. A comparative study of separation processes for bioethanol production; 2016

9. Kumar S, Singh N, Prasad R. Anhydrous ethanol: a renewable source of energy. Renew Sust Energ Rev. 2010;14(7):1830-44.

10. Bastidas PA, Gil ID, Rodríguez G. Comparison of the main ethanol dehydration technologies through process simulation. ESCAPE20; 2010.

11. Meirelles A, Weiss $S$, Herfurth $H$. Ethanol dehydration by extractive distillation. J Chem Tech Biotechnol. 1992:53:181-8.

12. Chuenbubpar D, Srinophakhun TR, Tohsakul P. Plant-wide process simulation of ethanol production from empty fruit bunch. KMUTNB Int Appl Sci Techhnol. 2018;11:53-61.

13. Bermudez $\mathrm{JH}$, Alvarez MET, Rojas JV, Filho RM. Pervaporation: promissory method for the bioethanol separation of fermentation. Chem Eng Trans. 2014;38:139-44.

14. Ravagnani MASS, Reis MHM, Filho M, Wolf-Maciel MR. Anhydrous ethanol production by extractive distillation: a solvent case study. Process Saf Environ Prot. 2010;88:67-73.

15. Kaminski W, Marszalek J, Ciolkowska A. Renewable energy source-dehydrated ethanol. Chem Eng J. 2008;135:95-102.

16. Hafrat M, Tgarguifa A, Abderafi S. Modeling of pervaporation process for the dehydration of bioethanol; 2015.

17. Khan SM, Usman M, Gull N, Butt MTZ, Jamil T. Dehydration of industrial ethanol by pervaporation. J Qual Technol. 2013:9(2):163-70.

18. Kunnakorn D, Rirksomboon T, Siemanond K, Aungkavattana P, Kuanchertchoo N, Chuntanalerg P, et al. Techno-economic comparison of energy usage between azeotropic distillation and hybrid system for waterethanol separation. Renew Energy. 2013;51:310-6.

19. Kazi FK, Fortman JA, Anex RP, Hsu DD, Aden A, Dutta A, Kothandaraman G. Techno-economic comparison of process technologies for biochemical ethanol production from corn stover. Fuel. 2010;89:20-8.

20. Jaksland CA, Gani R, Lien KM. Separation process design and synthesis based on thermodynamic insights. Chem Eng Sci. 1995;50(3):511-30.

21. Holtbruegge J, Kuhlmann H, Lutze P. Conceptual design of flowsheet options based on thermodynamic insights for (reaction-)separation processes applying process intensification. Ind Eng Chem Res. 2014;53: 13412-29.

22. Li C, Wozny G, Suzuki K. Design and synthesis of separation process based on a hybrid method. Asia Pac J Chem Eng. 2009;4(6):905-15.

23. Zabed H, Sahu JN, Boyce AN, Faruq G. Fuel ethanol production from lignocellulosic biomass: an overview on feedstocks and technological approaches. Renew Sustain Energy Rev. 2016;66:751-74.

24. Dias MOS, Ensinas AV, Nebra SA, Filho RM, Rossell CEV, Maciel MRW. Production of bioethanol and other bio-based materials from sugarcane bagasse: integration to conventional bioethanol production process. Chem Eng Res Des. 2009;87:1206-16.

25. Biegler LT, Grossmann IE, Westerberg AW. Systematic methods of chemical process design. 1st ed. Singapore: Prentice Hall; 1997.

26. Kalakul S, Malakul P, Siemanond K, Gani R. Integration of life cycle assessment software with tools for economic and sustainability analyses and process simulation for sustainable process design. J Clean Prod. 2014, 71:98-109.

27. Lee WG, Lee JS, Shin CS, Park SC, Chang HN, Chang YK. Ethanol production using concentrated oak wood hydrolysates and methods to detoxify. Appl Biochem Biotechnol. 1999;78(1-3):547-59.

28. Amaley SH, Sapkal RS, Sapkal VS. Pervaporation: a novel process for ethanol separation using fermentation. Int J Eng Res. 2015;2:64-8.

29. Chandel AK, Kapoor RK, Singh A, Kuhad RC. Detoxification of sugarcane bagasse hydrolysate improves ethanol production by Candida shehatae NCIM 3501. Bioresour Technol. 2007:98:1947-50.

30. Yeom CK, Huang RYM. Modelling of the pervaporation separation of ethanol - water mixtures through crosslinked poly (vinyl alcohol) membrane. J Membr Sci. 1992;67:39-55. 
31. Zhang J, Adrian FJ, Jahnke W, Cowan-Jacob SW, Li AG, Jacob RE. Targeting Bcr-Abl by combining allosteric with ATP-binding-site inhibitors. Nature. 2010;463(7280):501-6.

32. Martinez A, Rodriguez ME, Wells ML, York SW, Preston JF, Ingram LO. Detoxification of dilute acid hydrolysates of lignocellulose with lime. Biotechnol Prog. 2001;17:287-93.

33. Kamzon MA, Abderafi S, Bounahmidi T. Promising bioethanol processes for developing a biorefinery in the Moroccan sugar industry. Int I Hydrog Energy. 2016;41(45):20880-96.

34. Mosier N, Wyman C, Dale B, Elander R, Lee YY, Holtzapple M, Ladisch M. Features of promising technologies for pretreatment of lignocellulosic biomass. Bioresour Technol. 2005;96:673-86.

35. Quintero JA, Cardona CA. Process simulation of fuel ethanol production from lignocellulosics using aspen plus. Ind Eng Chem Res. 2011;50(10): 6205-12.

36. Wongtanyawat N, Lusanandana P, Khwanjaisakun N, Kongpanna P, Phromprasit J, Simasatitkul L, Amornraksa S, Assabumrungrat S. Comparison of different kraft lignin-based vanillin production processes. Comput Chem Eng. 2018;117:159-70.

37. Linzmeyer P, Souza PK, Souza O, Sellin N, Marangoni C. Comparison of different separation methods for solids removal in an ethanol fermentation broth from banana culture waste. Chem Eng Trans. 2014;37:355-60.

38. Malav MK, Prasad S, Kharia SK, Kumar S, Sheetal KR, Kannojiya S. Furfural and 5-HMF: potent fermentation inhibitors and their removal techniques. Int J Curr Microbiol App Sci. 2017;6(3):2060-6.

39. Kusolsongtawee T, Wuttilerts T, Chulalaksananukul S. Bioethanol production from Ceratophyllum demersum L. and carbon footprint evaluation. KMUTNB Int J Appl Sci Technol. 2018;11(2):103-8.

40. Kemcore. https://www.kemcore.com/sulphuric-acid-98.html. Accessed 15 May 2019.

41. Alibaba. https://www.alibaba.com . Accessed 15 May 2019.

42. Markets Insider. https://markets.businessinsider.com/commodities/ethanolprice . Accessed 15 May 2019.

43. Plasticinsight. https://www.plasticsinsight.com/resin-intelligence/resinprices/mono-ethylene-glycol-meg/ . Accessed 15 May 2019.

44. Seider WD, Seader JD, Lewin DR. Product \& process design principles: synthesis, analysis, and evaluation. 2nd ed. New York: Wiley; 2003.

45. Douglas J. Conceptual design of chemical process. Inter edition. Singapore: McGraw-Hill; 1988

\section{Publisher's Note}

Springer Nature remains neutral with regard to jurisdictional claims in published maps and institutional affiliations.

Ready to submit your research? Choose BMC and benefit from:

- fast, convenient online submission

- thorough peer review by experienced researchers in your field

- rapid publication on acceptance

- support for research data, including large and complex data types

- gold Open Access which fosters wider collaboration and increased citations

- maximum visibility for your research: over $100 \mathrm{M}$ website views per year

At BMC, research is always in progress.

Learn more biomedcentral.com/submissions 